\title{
Polymer coated gold-ferric oxide superparamagnetic nanoparticles for theranostic applications
}

\author{
Muhammad Raisul Abedin', Siddesh Umapathi ${ }^{2}$, Harika Mahendrakar ${ }^{1}$, Tunyaboon Laemthong ${ }^{1}$, \\ Holly Coleman², Denise Muchangi ${ }^{3}$, Santimukul Santra ${ }^{3}$, Manashi Nath $^{2}$ and Sutapa Barua ${ }^{1 *}$ (c)
}

\begin{abstract}
Background: Engineered inorganic nanoparticles (NPs) are essential components in the development of nanotechnologies. For applications in nanomedicine, particles need to be functionalized to ensure a good dispersibility in biological fluids. In many cases however, functionalization is not sufficient: the particles become either coated by a corona of serum proteins or precipitate out of the solvent. We show that by changing the coating of magnetic iron oxide NPs using poly-L-lysine (PLL) polymer the colloidal stability of the dispersion is improved in aqueous solutions including water, phosphate buffered saline (PBS), PBS with 10\% fetal bovine serum (FBS) and cell culture medium, and the internalization of the NPs toward living mammalian cells is profoundly affected.
\end{abstract}

Methods: A multifunctional magnetic NP is designed to perform a near-infrared (NIR)-responsive remote control photothermal ablation for the treatment of breast cancer. In contrast to the previously reported studies of gold (Au) magnetic $\left(\mathrm{Fe}_{3} \mathrm{O}_{4}\right.$ ) core-shell NPs, a Janus-like nanostructure is synthesized with $\mathrm{Fe}_{3} \mathrm{O}_{4} \mathrm{NPs}$ decorated with Au resulting in an approximate size of $60 \mathrm{~nm}$ mean diameter. The surface of trisoctahedral $\mathrm{Au}-\mathrm{Fe}_{3} \mathrm{O}_{4} \mathrm{NPs}$ was coated with a positively charged polymer, $\mathrm{PLL}$ to deliver the NPs inside cells. The PLL-Au-Fe $\mathrm{O}_{4} \mathrm{NPs}$ were characterized by transmission electron microscopy (TEM), XRD, FT-IR and dynamic light scattering (DLS). The unique properties of both Au surface plasmon resonance and superparamagnetic moment result in a multimodal platform for use as a nanothermal ablator and also as a magnetic resonance imaging (MRI) contrast agent, respectively. Taking advantage of the photothermal therapy, PLL-Au-Fe $\mathrm{O}_{4}$ NPs were incubated with BT-474 and MDA-MB-231 breast cancer cells, investigated for the cytotoxicity and intracellular uptake, and remotely triggered by a NIR laser of $\sim 808 \mathrm{~nm}\left(1 \mathrm{~W} / \mathrm{cm}^{2}\right.$ for $\left.10 \mathrm{~min}\right)$.

Results: The PLL coating increased the colloidal stability and robustness of $\mathrm{Au}-\mathrm{Fe}_{3} \mathrm{O}_{4} \mathrm{NPs}\left(\mathrm{PLL}-\mathrm{Au}-\mathrm{Fe}_{3} \mathrm{O}_{4}\right)$ in biological media including cell culture medium, PBS and PBS with $10 \%$ fetal bovine serum. It is revealed that no significant $(<10 \%)$ cytotoxicity was induced by PLL-Au- $\mathrm{Fe}_{3} \mathrm{O}_{4} \mathrm{NPs}$ itself in BT-474 and MDA-MB-231 cells at concentrations up to $100 \mathrm{\mu g} / \mathrm{ml}$. Brightfield microscopy, fluorescence microscopy and TEM showed significant uptake of PLL-Au-Fe $\mathrm{O}_{4} \mathrm{NPs}$ by BT-474 and MDA-MB-231 cells. The cells exhibited 40 and 60\% inhibition in BT-474 and MDA-MB-231 cell growth, respectively following the internalized NPs were triggered by a photothermal laser using $100 \mathrm{\mu g} / \mathrm{ml} \mathrm{PLL}-\mathrm{Au}-\mathrm{Fe}_{3} \mathrm{O}_{4} \mathrm{NPs}$. The control cells treated with NPs but without laser showed $<10 \%$ cell death compared to no laser treatment control

Conclusion: Combined together, the results demonstrate a new polymer gold superparamagnetic nanostructure that integrates both diagnostics function and photothermal ablation of tumors into a single multimodal nanoplatform exhibiting a significant cancer cell death.

\footnotetext{
*Correspondence: baruas@mst.edu

${ }^{1}$ Department of Chemical and Biochemical Engineering, Missouri

University of Science and Technology, 110 Bertelsmeyer Hall, $1101 \mathrm{~N}$

State Street, Rolla, MO 65409-1230, USA

Full list of author information is available at the end of the article
} 
Keywords: Breast cancer, Combination treatments, Gold-superparamagnetic nanoparticles, Magnetic resonance imaging (MRI), Photothermal treatment, Polymer coating

\section{Background}

Assembly of the hyperthermia property of superparamagnetic nanoparticles (NPs) with imaging function into a single nanostructure offers a promising way to dynamically monitor the progress of the disease and enhance therapeutic efficacy. Unlike single-component materials, which usually contain only one unique property of the active ingredient, the ingredients of multicomponent materials offer the possibility of multimodal application of these functional components thereby increasing versatility of these materials $[1$, 2]. The development of multicomponent materials as theranostic nanosystems has a potential to establish a new therapeutic mode to combine imaging and hyperthermia, which can greatly increase the therapeutic efficacy with real-time monitoring in tissues. Normal tissues and tumors differ only slightly in relaxation time, and hence, cannot propagate proper diagnosis signals during magnetic resonance imaging (MRI) [3]. The development of new MRI contrast agents based on NPs is a fascinating field of research that focuses on improving MRI techniques for the early detection of disease. Superparamagnetic NPs such as ferric oxide $\left(\mathrm{Fe}_{3} \mathrm{O}_{4}\right)$ have been extensively employed as an MRI contrast agent [4-10], altering the magnetic resonance (MR) signals by reducing the relaxivity through de-phasing of the transverse magnetization $[11,12]$. A gold $(\mathrm{Au})$ shell coating may be useful in this regard in order to enhance not only the imaging contrasts for MRI but also the photothermal effect via the plasmonderived optical resonances of gold shells in the visible and near-infrared region (NIR) [13]. The combination of Aucoated NPs has tremendous potential in improving optical properties, thermal properties, tunable geometry, and imaging contrasts in MRI. As a bifunctional NP, $\mathrm{Au}-\mathrm{Fe}_{3} \mathrm{O}_{4}$ can inherit excellent surface chemistry characteristics, unique optical properties (attributed to $\mathrm{Au}$ ) and superparamagnetic characteristics attributed to $\mathrm{Fe}_{3} \mathrm{O}_{4}$. First of all, the NPs offer size controllability, ranging from few to hundreds of nanometers with different and unique size-dependent properties. Second, the NPs can be easily controlled and manipulated from outside with the help of external magnetic field being operated from a distance. Third, the NPs can provide enhanced contrast in medical imaging that can be used to diagnose the situation efficiently. These characteristics would enhance and broaden the application of these nanoparticles for theranostic applications.

While only a few number of Au and magnetic NPs have been approved for clinical and preclinical trials by the U.S. Food and Drug Administration (FDA) [14-17], toxicity of both coated and uncoated magnetic NPs remain a serious concern [18-21]. Both $\mathrm{Au}$ and $\mathrm{Fe}_{3} \mathrm{O}_{4}$ NPs exhibit toxicity to cells via numerous mechanisms including the disruption of the cell membrane, DNA damage, induction of oxidative stress, generation of free radicals, impairment of mitochondrial function and alteration in cell signaling among others [22-24]. The toxicity may not be caused by single NP, but rather due to the aggregation of NPs in biological media and serum [25, 26]. Given the unstable nature of NP formulation, it is hypothesized that an optimum dose of a cationic polymer coating onto $\mathrm{Au}-$ $\mathrm{Fe}_{3} \mathrm{O}_{4}$ NPs play a role in determining NP configuration on cellular cytotoxicity as well as direct therapy. Coating the surface of $\mathrm{Au}-\mathrm{Fe}_{3} \mathrm{O}_{4}$ NPs with suitable polymers may offer several features: (i) reduced aggregation tendency of the particles; (ii) improved dispersibility; (iii) enhanced colloidal stability; (iv) protected undesirable surface oxidation; (iv) surface conjugation for targeting; (v) decreased cytotoxicity; and (vi) increased intracellular uptake by target cells. A charged polymer coating on the NP surface enhances the electrosteric stabilization by attractive and repulsive forces. Poly-L-lysine (PLL) is a biocompatible polycation that promotes cell adhesion by the presence of amine $\left(-\mathrm{NH}_{2}\right)$ groups [27-29]. PLL has been used to increase blood circulation, improve solubility as well as enhance MRI imaging contrasts of gadolinium imaging chelates [27, 29-32]. Steric stabilization has proven to be an effective method to improve NP colloidal stability in ionic media [33]. A uniform coating of $\mathrm{Fe}_{3} \mathrm{O}_{4}$ NPs with polysaccharides leads to a decrease in saturation magnetization as compared to uncoated particles [34]. This drop in saturation magnetization is undesirable due to poor signaling in MRI imaging. Therefore, there is a need for a stable coating on the surface of $\mathrm{Au}-\mathrm{Fe}_{3} \mathrm{O}_{4}$ NPs to prepare a colloidal dispersion in the biological medium and attain high MRI imaging contrasts.

In this study, multifunctional $\mathrm{Au}-\mathrm{Fe}_{3} \mathrm{O}_{4}$ NPs were designed for medical imaging and hyperthermal treatments of breast cancer cells. To overcome the limitation of colloidal stability and low dispersity of NPs, a PLL polymeric coating was introduced to the surface of $\mathrm{Au}-\mathrm{Fe}_{3} \mathrm{O}_{4}$ as a physical barrier for preventing NP aggregation as well as enhancing their intracellular uptake by breast cancer cells. Our results showed that the PLL coating on $\mathrm{Au}-\mathrm{Fe}_{3} \mathrm{O}_{4}$ enhanced it stability in biological fluids such as water, phosphate buffered saline (PBS), cell culture medium and PBS containing $10 \%$ fetal bovine serum (FBS). PLL coated $\mathrm{Au}-\mathrm{Fe}_{3} \mathrm{O}_{4}$ NPs further enhanced the contrast of MRI imaging signals, exhibited intracellular uptake 
across the breast cancer cell membrane and decreased the cancer cell viability following photothermal treatment. The novelty of this work is to generate a nanometer-thick PLL layer for the stable dispersion of $\mathrm{Au}-\mathrm{Fe}_{3} \mathrm{O}_{4}$ NPs in biological fluids that results in excellent optical, magnetic and therapeutic properties for the cancer treatment.

\section{Methods}

\section{Synthesis of $\mathrm{Au}-\mathrm{Fe}_{3} \mathrm{O}_{4} \mathrm{NPs}$}

The $\mathrm{Au}-\mathrm{Fe}_{3} \mathrm{O}_{4}$ NPs were synthesized by a one-pot synthesis technique based on the method that has been published by Pariti et al. [35]. Briefly, the NPs were synthesized by injecting $2.5 \mathrm{mM}$ of $\mathrm{Fe}(\mathrm{CO})_{5}, 0.25 \mathrm{mM}$ of $\mathrm{HAuCl}_{4}, 2.5 \mathrm{mM}$ oleic acid, and $2.5 \mathrm{mM}$ of oleylamine into $5 \mathrm{ml}$ of Triton ${ }^{\circledR} \mathrm{X}-100$ at $85{ }^{\circ} \mathrm{C}$. The reaction was conducted for $10 \mathrm{~min}$ in a three-neck round bottom flask equipped with a magnetic stir bar and air condenser. The temperature was increased to $300{ }^{\circ} \mathrm{C}$. The product was a black precipitate that was isolated from the reaction mixture by magnetic filtration, followed by ultrasonication, centrifugation, and washing to remove excess Triton ${ }^{\circledR}$ $\mathrm{X}-100$ and any unreacted precursors. The powder collected at the bottom of the centrifuge tube was dried in air. The preparation of $\mathrm{Au}-\mathrm{Fe}_{3} \mathrm{O}_{4} \mathrm{NPs}$ was confirmed by $\mathrm{XRD}$ analysis using a $\mathrm{D} / \mathrm{max}-2400$ diffractometer and $\mathrm{CuK}$ radiation $(\lambda=0.1541 \mathrm{~nm})$.

\section{Polymer coating on $\mathrm{Au}-\mathrm{Fe}_{3} \mathrm{O}_{4} \mathrm{NPs}$}

To coat the NP surface with PLL, $660 \mu \mathrm{l}$ of $0.1 \%\left(\frac{w}{v}\right)$ PLL (Sigma Aldrich, MW: 150,000-300,000) was added to $25 \mathrm{mg}$ of $\mathrm{Au}-\mathrm{Fe}_{3} \mathrm{O}_{4} \mathrm{NPs}$ and incubated for $24 \mathrm{~h}$ at room temperature $\left(\sim 22^{\circ} \mathrm{C}\right)$ under continuous shaking. Unbound PLL was removed by centrifuging at $5000 \times g$ for $30 \mathrm{~min}$ that was repeated twice and measured using the trypan blue assay, spectrophotometry, and a standard curve (Additional file 1: Figure S1a) [36]. The concentration of $\mathrm{Au}-\mathrm{Fe}_{3} \mathrm{O}_{4}$ NPs was determined using a standard curve of the NP absorption at $710 \mathrm{~nm}$ peak (Additional file 1: Figure S1b). The mass ratio of PLL and NPs were calculated. The presence of PLL coating was confirmed by Fourier Transform Infrared (FT-IR) spectroscopy. The FT-IR spectrometer (Perkin-Elmer) was equipped with an electronic temperature control (ETC) EverGlo IR Source and a deuterated triglycine sulfate (DTGS) detector. FT-IR analysis was carried out for uncoated and PLL coated $\mathrm{Au}-\mathrm{Fe}_{3} \mathrm{O}_{4} \mathrm{NPs}$ by mixing with potassium bromide $(\mathrm{KBr})$ and a pellet method, after a baseline correction being made with dried $\mathrm{KBr}$, to confirm the compatibility. The pellet was prepared to a pressure of about $5 \times 10^{6} \mathrm{~Pa}$, in an evacuated chamber, to produce a clear transparent disc of diameter $2 \mathrm{~cm}$ and thickness of $0.2 \mathrm{~cm}$. The spectra were recorded at room temperature $\left(\sim 25^{\circ} \mathrm{C}\right)$ from 4000 to $400 \mathrm{~cm}^{-1}$.

\section{Nanoparticle characterization}

To measure the $d_{\text {mean }}$ of $\mathrm{Au}-\mathrm{Fe}_{3} \mathrm{O}_{4}$ and PLL- $\mathrm{Au}-\mathrm{Fe}_{3} \mathrm{O}_{4}$ NPs, transmission electron microscope (TEM) images were obtained using a Tecnai F20 at an accelerating voltage of $120 \mathrm{kV}$. A drop of $10 \mu \mathrm{l}$ of each NP sample in water was air-dried on carbon-coated copper grids (Ted Pella). Images were recorded and analyzed using ImageJ (version $1.45 \mathrm{~S}, \mathrm{NIH}, \mathrm{USA})$ to calculate $d_{\text {mean }}$ for at least 20 particles. The size distribution of $\mathrm{Au}-\mathrm{Fe}_{3} \mathrm{O}_{4}$ and PLL-Au$\mathrm{Fe}_{3} \mathrm{O}_{4}$ NPs was determined by dynamic light scattering (DLS). The zeta potential was measured via laser Doppler anemometry using a Zetasizer Nano ZS (Malvern Instruments). Samples were prepared in water, PBS, RPMI 1640 cell culture medium and PBS with 10\% FBS. Measurements were performed in triplicates and shown as the mean \pm standard deviation (S.D.). The X-ray diffraction (XRD) patterns were performed by a Philips X-Pert X-ray powder diffractometer with $\mathrm{CuK} \alpha(1.5418 \AA$ ) radiation from 5 to $90^{\circ}$. The UV-Vis absorption spectra of $\mathrm{Au}-$ $\mathrm{Fe}_{3} \mathrm{O}_{4}$ and PLL-Au- $\mathrm{Fe}_{3} \mathrm{O}_{4}$ NPs were measured using a Bio-Tek microplate reader (BioTek Synergy 2) between 400 and $900 \mathrm{~nm}$. Fourier transform infrared (FT-IR) spectroscopy of $\mathrm{Au}-\mathrm{Fe}_{3} \mathrm{O}_{4}$ and PLL- $\mathrm{Au}-\mathrm{Fe}_{3} \mathrm{O}_{4}$ NPs was carried out using a Perkin Elmer Spectrum GX spectrophotometer. Thermal gravimetric analysis (TGA) was performed using a Q50 thermal gravimetric analyzer (TA instruments). The samples were heated from 25 to $1000^{\circ} \mathrm{C}$ at a heating rate of $10{ }^{\circ} \mathrm{C} / \mathrm{min}$ under $\mathrm{N}_{2}$ flow. Results are expressed in weight percent as a function of temperature.

\section{Spin-spin magnetic relaxation (T2 ms) studies of PLL-Au- $\mathrm{Fe}_{3} \mathrm{O}_{4} \mathrm{NPs}$}

To measure the relaxation variables in MRI, $\mathrm{Au}-\mathrm{Fe}_{3} \mathrm{O}_{4} \mathrm{NPs}$ coated with PLL (PLL-Au- $\mathrm{Fe}_{3} \mathrm{O}_{4}$ ) were prepared in water at $100 \mu \mathrm{g} / \mathrm{ml}$ concentration. All measurements were conducted at $37^{\circ} \mathrm{C}$ using a Bruker's magnetic relaxometer mq20 $(0.47 \mathrm{~T}, \mathrm{~B}=20 \mathrm{MHz})$ for the spin-spin magnetic relaxation time $\left(\mathrm{T}_{2}\right)$ experiments. The specimens were dispersed in PBS and PBS containing $10 \% \mathrm{FBS}$ at different $\mathrm{Au}-\mathrm{Fe}_{3} \mathrm{O}_{4}$ and PLL- $\mathrm{Au}-\mathrm{Fe}_{3} \mathrm{O}_{4} \mathrm{NP}$ concentrations $(1,10$ and $100 \mu \mathrm{g} /$ $\mathrm{ml})$. The proton spin-spin magnetic relaxation time, $\mathrm{T}_{2}$ was measured as a function of the NP concentration.

\section{Cytotoxicity of PLL-Au- $\mathrm{Fe}_{3} \mathrm{O}_{4} \mathrm{NPs}$ in Breast Cancer Cells}

BT-474 and MDA-MB-231 breast cancer cells (ATCC) were cultured at $37^{\circ} \mathrm{C}$ and $5 \% \mathrm{CO}_{2}$ in Hybri-Care (ATCC) and RPMI 1640 (Life Technologies), respectively supplemented with 10\% FBS (Corning) and 1\% (100 units/ml) Penicillin-Streptomycin (Gibco). Cells in the exponential growth phase were seeded in a 96-well plate at an initial density of 10,000 cells/well and incubated overnight. Different concentrations of PLL- $\mathrm{Au}-\mathrm{Fe}_{3} \mathrm{O}_{4} \mathrm{NPs}(0-500 \mu \mathrm{g} /$ $\mathrm{ml}$ ) were added to the cell culture media. After $2 \mathrm{~h}$ of 
incubation, the media was removed, and the cells were washed using PBS followed by re-incubation in cell culture media for additional $72 \mathrm{~h}$. The viable and dead cells were measured using a live-dead (calcein AM; CAM and EthD-1) assay (Invitrogen) and calculated according to the manufacturer's protocol. The cells without any NP treatments were used as the control. The percentage cell death was calculated by the following equation:

$$
\% \text { cell death }=\frac{F_{N P s}-F_{\text {blank }}}{F_{\text {control }}-F_{\text {blank }}} \times 100
$$

where $\mathrm{F}_{\mathrm{NPs}}$ is the Ethd-1 fluorescence of the cells treated with PLL- $\mathrm{Au}-\mathrm{Fe}_{3} \mathrm{O}_{4} \mathrm{NPs}, \mathrm{F}_{\text {blank }}$ is the Ethd-1 fluorescence of the cell culture medium alone, and $\mathrm{F}_{\text {control }}$ is the Ethd-1 fluorescence of the cells without any NP treatments. The concentration at which cell death was less than $10 \%$ was identified as a non-toxic dose.

\section{Intracellular uptake of PLL-Au- $\mathrm{Fe}_{3} \mathrm{O}_{4} \mathrm{NPs}$}

Cellular uptake of PLL-Au-Fe $\mathrm{O}_{4}$ NPs was observed using a Carl Zeiss Axio observer Z1 research microscope system with Apotome. 2 optical structuring device. BT-474 and MDA-MB-231 cells were seeded in 8-well chambers containing 10,000 cells/well and grown until $70 \%$ confluence. $\mathrm{PLL}-\mathrm{Au}-\mathrm{Fe}_{3} \mathrm{O}_{4} \mathrm{NPs}$ of $100 \mu \mathrm{g} / \mathrm{ml}$ were added to the wells, incubated for $2 \mathrm{~h}$, and washed using PBS for three times. Live cells were re-incubated with media and imaged on a Zeiss microscope using a $63 \times$ objective (water) through phase contrast. The intracellular uptake of PLL-Au$\mathrm{Fe}_{3} \mathrm{O}_{4}$ NPs by BT-474 and MDA-MB-231 cells were further examined by TEM at a voltage of $80 \mathrm{kV}$. Briefly, cells were seeded in T25 flasks at a density of $1 \times 10^{6}$ cells $/ \mathrm{ml}$. After overnight incubation at $37{ }^{\circ} \mathrm{C}$ and $5 \% \mathrm{CO}_{2}$, the cells were incubated with $100 \mu \mathrm{g} / \mathrm{ml} \mathrm{PLL}-\mathrm{Au}-\mathrm{Fe}_{3} \mathrm{O}_{4} \mathrm{NPs}$. After incubation for another $24 \mathrm{~h}$, the medium was carefully removed and cells were washed with PBS for three times and fixed at $4{ }^{\circ} \mathrm{C}$ for $1 \mathrm{~h}$ using glutaraldehyde $(2.5 \%$ in PBS). Then the cells were further subjected to a sequence of treatments to obtain sections that were subsequently mounted on copper grids before TEM measurements.

\section{Photothermal treatment of breast cancer cells using PLL- $\mathrm{Au}-\mathrm{Fe}_{3} \mathrm{O}_{4} \mathrm{NPs}$}

A series of specimens with different PLL- $\mathrm{Au}-\mathrm{Fe}_{3} \mathrm{O}_{4} \mathrm{NP}$ concentrations $(0,50,100,200,400$ and $800 \mu \mathrm{g} / \mathrm{ml})$ were put into quartz cuvettes and irradiated by an $808 \mathrm{~nm}$ laser for $10 \mathrm{~min}$ with $1 \mathrm{~W} / \mathrm{cm}^{2}$ power density. An in situ thermocouple thermometer (Cole-Parmer) was used to record the temperature change. To investigate the in vitro photothermal ablation of breast cancer cells, BT-474 and MDA-MB-231 cells were incubated with $100 \mu \mathrm{g} / \mathrm{ml}$ of PLL-Au- $\mathrm{Fe}_{3} \mathrm{O}_{4}$ NPs in cell culture media for $2 \mathrm{~h}$, washed using PBS $(3 \times)$ to remove the unbound NPs and re-incubated in the corresponding cell culture media for $72 \mathrm{~h}$. The cells were exposed to NIR light $(808 \mathrm{~nm}$ pulse laser of $1 \mathrm{~W} /$ $\mathrm{cm}^{2}$ with a diameter of $6 \mathrm{~mm}$ for $10 \mathrm{~min}$ ) to induce photothermal damage. The following control samples were used: cell culture medium, cells without any treatment, and the cells treated with PLL- $\mathrm{Au}-\mathrm{Fe}_{3} \mathrm{O}_{4} \mathrm{NPs}$ without any exposure to lasers. After exposure to the NIR light, cells were incubated for an additional $72 \mathrm{~h}$ at $37^{\circ} \mathrm{C}$. Cell viability was assessed using CAM and EthD-1 (Invitrogen). To further confirm the in vitro photothermal ablation of breast cancer cells, cytotoxicity following irradiation was also performed using MTT viability assay (Invitrogen). Briefly, BT-474 and MDA-MB-231 cells were seeded in a 96-well plate at a density of 10,000 cells/well. After overnight incubation at $37{ }^{\circ} \mathrm{C}$ and $5 \% \mathrm{CO}_{2}$, cells were incubated with $\mathrm{PLL}-\mathrm{Au}-\mathrm{Fe}_{3} \mathrm{O}_{4}$ NPs of 0, 50, 100, 200, 400 and $800 \mu \mathrm{g} /$ $\mathrm{ml}$ for $2 \mathrm{~h}$. The medium was replaced with $100 \mu \mathrm{l}$ of fresh medium. A $10 \mu \mathrm{l} \mathrm{MTT} \mathrm{of} 5 \mathrm{mg} / \mathrm{ml}$ in PBS was added to the medium. Cells were incubated at $37^{\circ} \mathrm{C}$ for $4 \mathrm{~h}$ for labeling cells with MTT. All medium was removed from the well except $25 \mu \mathrm{l}$. A $50 \mu \mathrm{l}$ DMSO was added to each well for dissolving the insoluble formazan crystals. The absorbance at $540 \mathrm{~nm}$ was recorded using a Bio-Tek microplate reader (Synergy 2). Mean and standard deviations of two independent experiments were reported for each sample.

\section{Statistical analysis}

Each experiment was carried out with three independent experiments of at least triplicate measurements. The mean differences and standard deviations were evaluated.

\section{Results}

\section{Synthesis and characterization of PLL-Au- $\mathrm{Fe}_{3} \mathrm{O}_{4} \mathrm{NPs}$}

TEM images revealed that $\mathrm{Au}-\mathrm{Fe}_{3} \mathrm{O}_{4}$ NPs were uniform and averaged $\sim 55 \pm 8.6 \mathrm{~nm}$ in diameter (Fig. 1a). The thickness of PLL coating on $\mathrm{Au}-\mathrm{Fe}_{3} \mathrm{O}_{4}$ was estimated to be approximately $9 \pm 2.5 \mathrm{~nm}$ by analyzing the TEM images (Fig. 1b and c). Additional file 1: Table S1 shows the amount of PLL coating on $\mathrm{Au}-\mathrm{Fe}_{3} \mathrm{O}_{4}$. The hydrodynamic diameter of $\mathrm{Au}-\mathrm{Fe}_{3} \mathrm{O}_{4} \mathrm{NPs}$ in water as characterized using DLS showed a wide size distribution of $\mathrm{Au}-\mathrm{Fe}_{3} \mathrm{O}_{4}$ dispersions with more than one particle populations and a high polydispersity index (PDI) of $0.856 \pm 0.07$ (Additional file 1: Figure S2a). The differences in size between TEM and DLS techniques could be explained by NP agglomeration and the presence of small aggregates. The PLL coating decreased the PDI of $\mathrm{Au}-\mathrm{Fe}_{3} \mathrm{O}_{4} \mathrm{NPs}$ from 0.856 to $0.539 \pm 0.03$ (Table 1). The hydrodynamic diameters of NPs after PLL coating eliminated the large and small particle aggregates in water, PBS, RPMI 1640 cell culture medium and PBS containing 10\% FBS indicating a better colloidal stability (Additional 


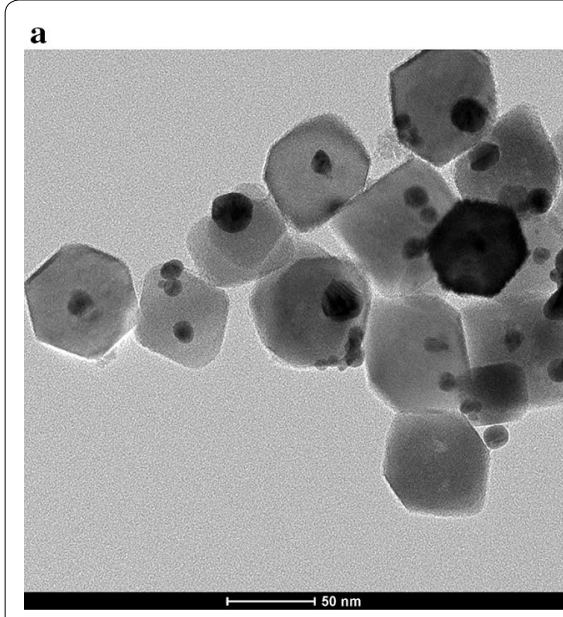

\section{b}

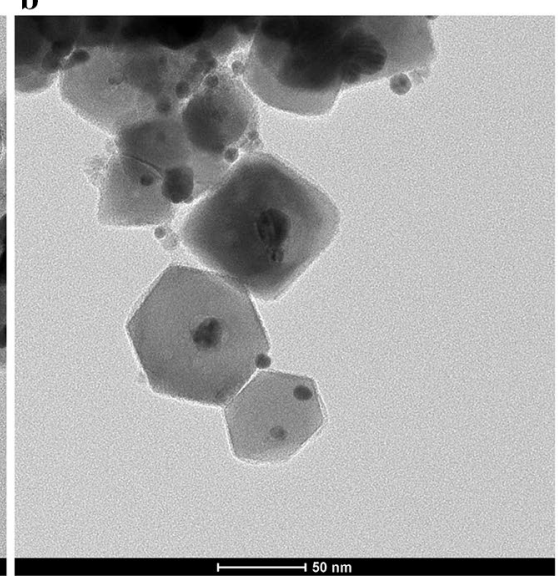

c

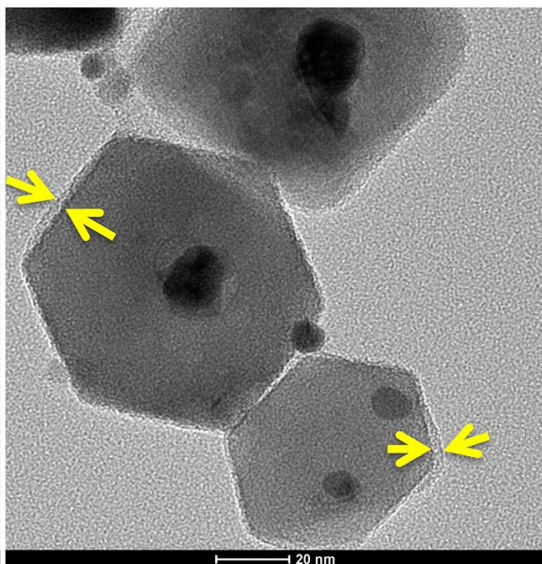

Fig. 1 TEM images showing Au-Fe $\mathrm{O}_{4} \mathrm{NPs}$ a without, and $\mathbf{b}$, c with PLL coating. Scale bar $=50 \mathrm{~nm}$ in $\mathbf{a}$, b, and $20 \mathrm{~nm}$ in $\mathbf{c}$. The dark black circles indicate $\mathrm{Au}$ and the shaded hexagons represent $\mathrm{Fe}_{3} \mathrm{O}_{4}$. Arrows in $\mathbf{c}$ indicate a thin layer of PLL coating

Table 1 Characterization of $\mathrm{Au}-\mathrm{Fe}_{3} \mathrm{O}_{4}$ before and after PLL coating

\begin{tabular}{|c|c|c|c|c|c|}
\hline \multirow[t]{2}{*}{ Samples } & \multicolumn{5}{|c|}{$\zeta$-potential $(\mathrm{mV})$ in various biological medium } \\
\hline & PDI & Water & PBS & Cell culture medium & $\mathrm{PBS}+10 \% \mathrm{FBS}$ \\
\hline $\mathrm{Au}-\mathrm{Fe}_{3} \mathrm{O}_{4}$ & $0.856 \pm 0.07$ & $-7.9 \pm 0.8$ & $-12 \pm 7$ & $-3.4 \pm 5.2$ & $-4.8 \pm 2.6$ \\
\hline PLL-Au- $-\mathrm{Fe}_{3} \mathrm{O}_{4}$ & $0.539 \pm 0.03$ & $35 \pm 10$ & $26 \pm 8.5$ & $15.8 \pm 9.2$ & $16 \pm 6.8$ \\
\hline
\end{tabular}

file 1: Figure S2b). The stability of PLL-Au- $\mathrm{Fe}_{3} \mathrm{O}_{4} \mathrm{NPs}$ was further proved using a time-resolved video (Additional file 2: Movie S1). As you can see from this video that $\mathrm{Au}-\mathrm{Fe}_{3} \mathrm{O}_{4} \mathrm{NPs}$ without any coating (left-hand side tube in the video) precipitate down quickly in water while PLL-Au- $-\mathrm{Fe}_{3} \mathrm{O}_{4}$ NPs (right-hand side tube) were stably suspended in the black emulsion.

The $\mathrm{Au}-\mathrm{Fe}_{3} \mathrm{O}_{4}$ NPs possess a negative surface charge of $-7.9 \pm 0.8 \mathrm{mV}$ and $-12 \pm 7 \mathrm{mV}$ in water and PBS, respectively as determined by zeta potential (Table 1 and Fig. 2a). The zeta potentials of $\mathrm{Au}-\mathrm{Fe}_{3} \mathrm{O}_{4} \mathrm{NPs}$ increased in cell culture medium and PBS with $10 \%$ FBS indicating pronounced differences in the particle surface chemistry caused by different solvent compositions. The PLL coated $\mathrm{Au}-\mathrm{Fe}_{3} \mathrm{O}_{4}$ NPs showed a strong positive charge in water and PBS due to the positive amine groups on the polymer backbone which confirmed the successful grating of PLL polymer on the surface of NPs (Table 1 and Fig. 2b). This further confirms that the PLL coating made the NPs disperse better in aqueous solutions and as a result no agglomeration on storage. Particles that are surface engineered with amine functional groups like PLL has been reported to the effective release of encapsulated molecules from endosomal compartments [37].

The crystal structures of $\mathrm{Au}-\mathrm{Fe}_{3} \mathrm{O}_{4}$ and PLL-Au$\mathrm{Fe}_{3} \mathrm{O}_{4}$ NPs were recorded by the X-ray diffraction (XRD), as shown in Fig. 3a. The XRD pattern of $\mathrm{Fe}_{3} \mathrm{O}_{4}$ shows characteristic peaks at (111), (220), (311), (400), (422), (511) and (440), and (111), (200), (220), (311), (222) peaks for $\mathrm{Au}$ which is in agreement to the controls of $\mathrm{Fe}_{3} \mathrm{O}_{4}-$ PDF \# 65-3107 and Au-PDF \# 05-0681, respectively. XRD pattern contains no impurity peak indicating the high purity of $\mathrm{Au}$ and $\mathrm{Fe}_{3} \mathrm{O}_{4}$ samples and perfect phase transformation. The XRD pattern of PLL-Au- $\mathrm{Fe}_{3} \mathrm{O}_{4} \mathrm{NPs}$ has similar diffraction peaks as those of $\mathrm{Au}-\mathrm{Fe}_{3} \mathrm{O}_{4} \mathrm{NPs}$ with more peak to noise ratio which could be attributed to PLL polymeric coating.

To confirm the successful synthesis of NPs, UV-Vis absorption and FT-IR spectra were measured. A complete spectra analysis of $\mathrm{Au}-\mathrm{Fe}_{3} \mathrm{O}_{4}$ NPs shows a broad surface plasmon absorption with an absorption maximum at around $710 \mathrm{~nm}\left(\lambda_{\max }\right)$ (Fig. 3b; dotted line) [38]. The PLL coating showed an absorption shift to lower wavelengths with an absorption maximum at $640 \mathrm{~nm}$ (Fig. 3b; solid line). This explains the enhanced dispersion of PLL-Au- $\mathrm{Fe}_{3} \mathrm{O}_{4}$ NPs in the aqueous phase by redistributing agglomerated $\mathrm{Au}-\mathrm{Fe}_{3} \mathrm{O}_{4}$ NPs.

FT-IR spectra were used to study the transformation of $\mathrm{Au}-\mathrm{Fe}_{3} \mathrm{O}_{4}$ and PLL-Au- $\mathrm{Fe}_{3} \mathrm{O}_{4}$ NP compositions (Fig. 3c). As shown in Fig. 3c, the strong absorption peak at about $590 \mathrm{~cm}^{-1}$ in the FT-IR of $\mathrm{Au}-\mathrm{Fe}_{3} \mathrm{O}_{4}$ originates from $\mathrm{Fe}-\mathrm{O}$ stretching of the $\mathrm{Fe}_{3} \mathrm{O}_{4}$ core. The bare 

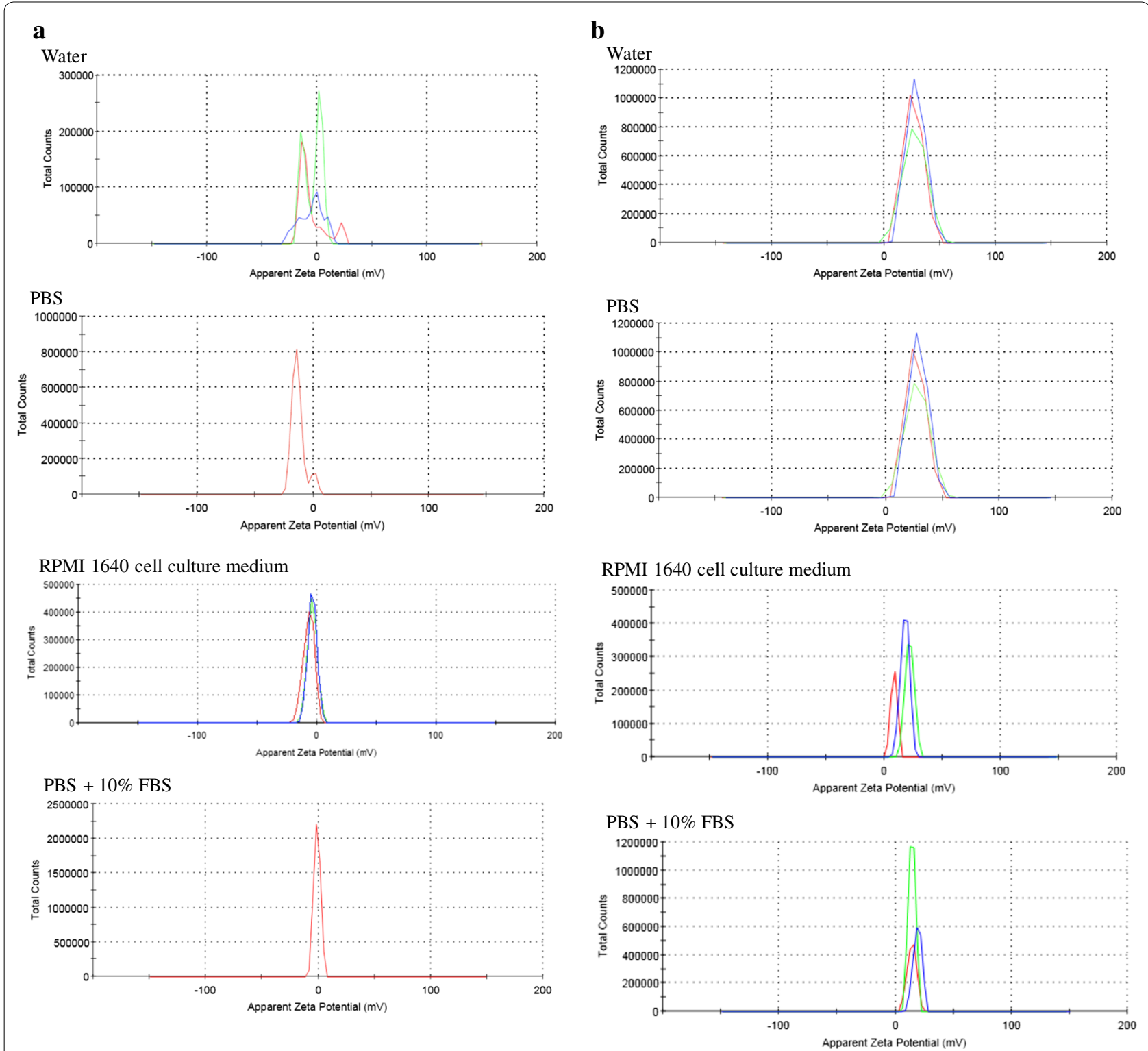

Fig. 2 Surface zeta potential of a Au-Fe $\mathrm{O}_{4}$, and $\mathbf{b} \mathrm{PLL}-\mathrm{Au}-\mathrm{Fe}_{3} \mathrm{O}_{4} \mathrm{NPs}$ in water, PBS, RPMl 1640 cell culture medium and PBS containing 10\% FBS. Three colored (red, green and blue) lines indicate three replicates from three independent experiments. Multiple peaks in $\mathrm{Au}-\mathrm{Fe}_{3} \mathrm{O}_{4}(\mathbf{a})$ indicate their aggregation behavior that disappears after PLL coating (b)

$\mathrm{Au}-\mathrm{Fe}_{3} \mathrm{O}_{4}$ spectrum contains a peak at $1630 \mathrm{~cm}^{-1}$ due to water physisorbed on the iron oxide surface and a broad band around $3400 \mathrm{~cm}^{-1}$ due to surface hydroxyl groups $(\mathrm{Fe}-\mathrm{OH})$. For PLL- $\mathrm{Au}-\mathrm{Fe}_{3} \mathrm{O}_{4} \mathrm{NPs}$, new and broad absorption bands were observed in the range of 3340 and $3600 \mathrm{~cm}^{-1}$, which were attributed to amine $\mathrm{N}-\mathrm{H}$ stretching and $\mathrm{O}-\mathrm{H}$ stretching, respectively. The peaks at 1647 and $1587 \mathrm{~cm}^{-1}$ attributed to the stretching vibration of $\mathrm{C}=\mathrm{O}$ from the PLL coating.

To quantify the amount of PLL on the surface of PLL$\mathrm{Au}-\mathrm{Fe}_{3} \mathrm{O}_{4}$ NPs, TGA was performed (Fig. 3d). The PLL coating results in a weight loss of $7.4 \%$ between 100 and
$650{ }^{\circ} \mathrm{C}$ when compared with the uncoated particles ( $\mathrm{Au}-$ $\mathrm{Fe}_{3} \mathrm{O}_{4}$ ). No change in PLL-Au- $\mathrm{Fe}_{3} \mathrm{O}_{4}$ mass was observed above $850{ }^{\circ} \mathrm{C}$. Combinedly these findings suggest a successful surface functionalization of $\mathrm{Au}-\mathrm{Fe}_{3} \mathrm{O}_{4} \mathrm{NPs}$ by PLL polymer coating.

Determination of $\mathrm{T}_{2}$ magnetic relaxation of $\mathrm{Au}-\mathrm{Fe}_{3} \mathrm{O}_{4}$ and PLL-Au- $\mathrm{Fe}_{3} \mathrm{O}_{4} \mathrm{NPs}$ using magnetic relaxometer

It is important to determine the overall magnetic properties of $\mathrm{Au}-\mathrm{Fe}_{3} \mathrm{O}_{4}$ and PLL- $\mathrm{Au}-\mathrm{Fe}_{3} \mathrm{O}_{4} \mathrm{NPs}$ for cancer imaging by MRI technique. It is expected that the synthesize $\mathrm{Fe}_{3} \mathrm{O}_{4}$ nanocomposites will be MR active as they are 

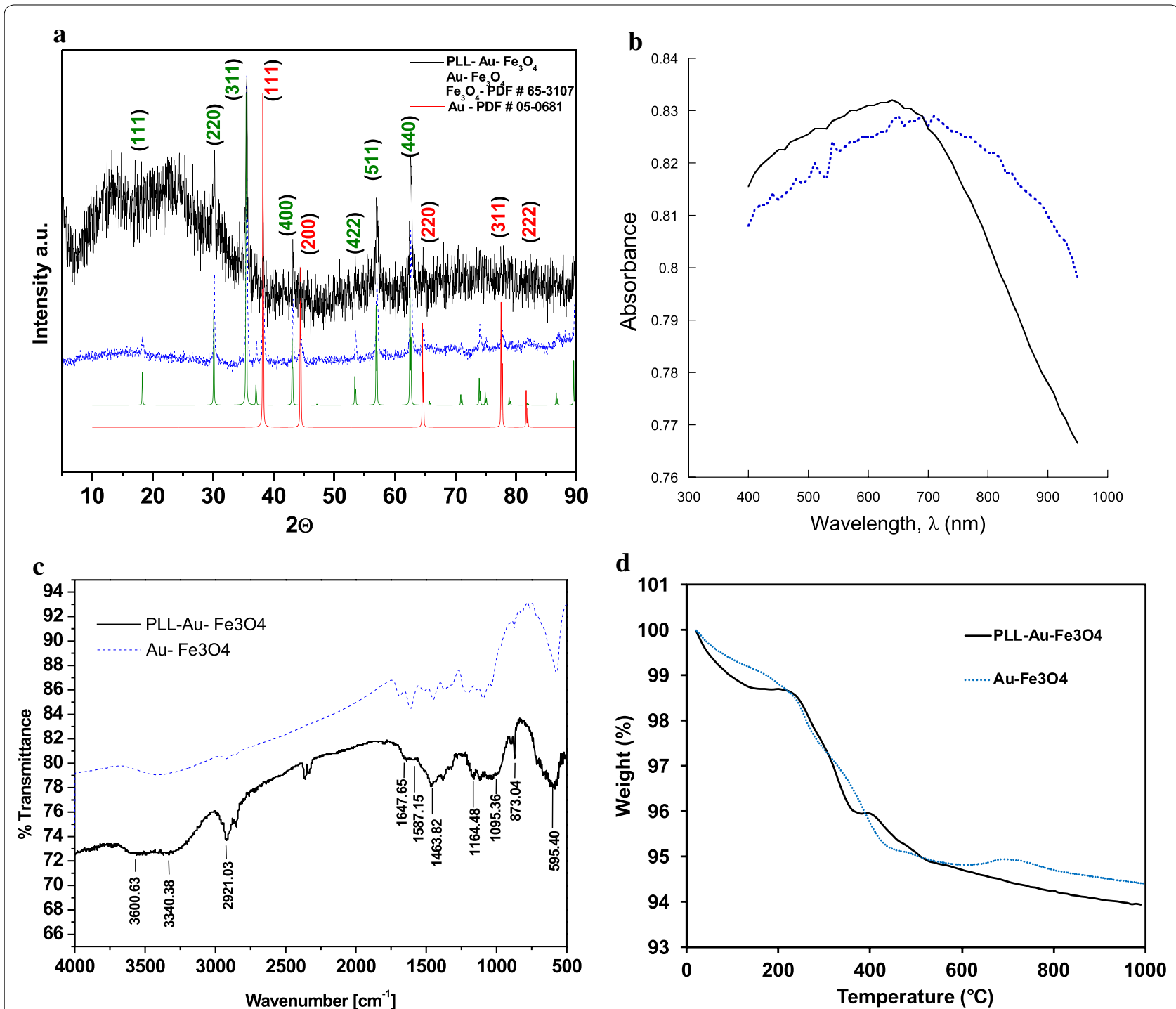

Fig. 3 a XRD patterns; b Absorption spectra (solid line: PLL-Au- $\mathrm{Fe}_{3} \mathrm{O}_{4} \mathrm{NPs}$ and dotted line: $\mathrm{Au}-\mathrm{Fe}_{3} \mathrm{O}_{4} \mathrm{NPs}$ ); $\mathbf{c}$ FT-IR characterization and $\mathbf{d}$ TGA curves of $\mathrm{Au}-\mathrm{Fe}_{3} \mathrm{O}_{4}$ and PLL-Au-Fe $\mathrm{O}_{4} \mathrm{O}_{4}$ NPs

superparamagnetic in nature. The spin-spin MR times $\left(\mathrm{T}_{2} \mathrm{~ms}\right)$ were analyzed in order to evaluate the magnetic properties of $\mathrm{Au}-\mathrm{Fe}_{3} \mathrm{O}_{4}$ with and without the PLL coating (Additional file 1: Figure S3). Generally, the spinspin magnetic relaxation of water protons changes in the presence of magnetic materials in the solution, such as synthesized $\mathrm{Au}-\mathrm{Fe}_{3} \mathrm{O}_{4} \mathrm{NPs}$. This leads to enhance the magnetic property of the solution. $\mathrm{Fe}_{3} \mathrm{O}_{4}$ NPs are generally used for MR contrast agents because of their capacity to shorten the $\mathrm{T}_{2}$ relaxation time of their surrounding protons. As can be clearly seen in Additional file 1: Figure $\mathrm{S} 3, \mathrm{~T}_{2}$ was decreased gradually with the increase in NP concentration. The $\mathrm{T}_{2}$ relaxation time of PLL-Au$\mathrm{Fe}_{3} \mathrm{O}_{4}$ NPs was higher than that of $\mathrm{Au}-\mathrm{Fe}_{3} \mathrm{O}_{4}$ NPs due to the fact that the polymer coating displaces the water molecules from the vicinity of the $\mathrm{Au}-\mathrm{Fe}_{3} \mathrm{O}_{4}$ nanocomposite, leading to an increase in the MR values. However, at higher concentrations, the MR values are comparable and the PLL-coated $\mathrm{Au}-\mathrm{Fe}_{3} \mathrm{O}_{4}$ NPs would be ideal for cancer imaging due to the higher bioavailability and minimal cytotoxicity. These results indicated that the formulated nanocomposites are superparamagnetic and ideal for cancer MR imaging.

\section{Cytotoxicity study by PLL-Au- $\mathrm{Fe}_{3} \mathrm{O}_{4} \mathrm{NPs}$ and its intracellular uptake}

Figure 4a shows the cytotoxicity induced by various concentrations of PLL- $\mathrm{Au}-\mathrm{Fe}_{3} \mathrm{O}_{4} \mathrm{NPs}$ in BT-474 and 


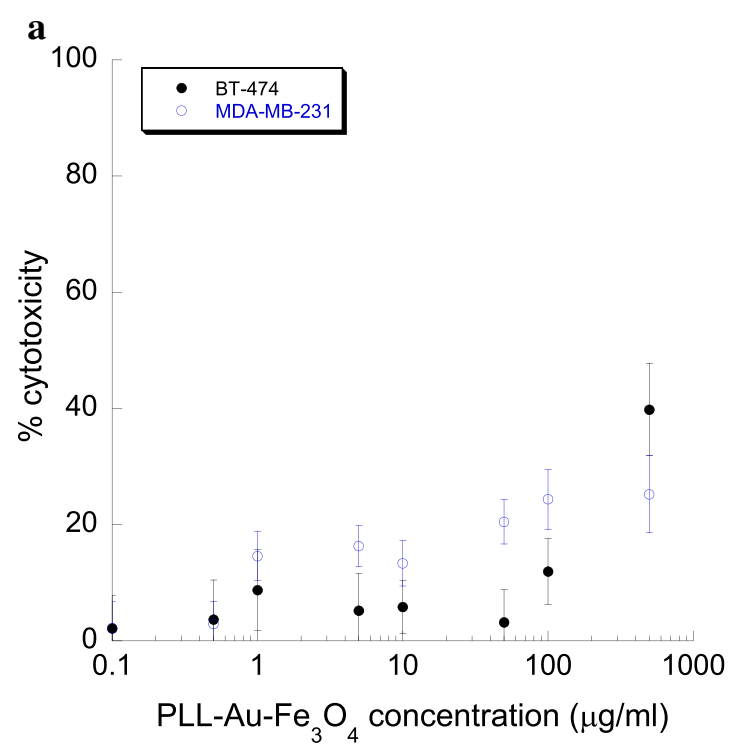

b BT-474 cells control; no NPs

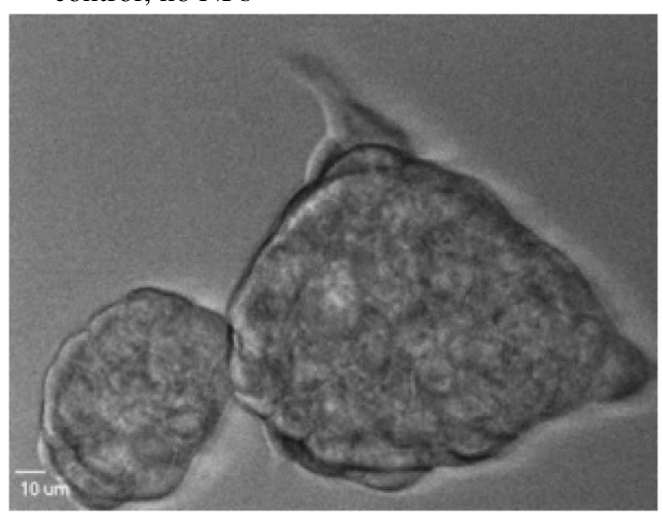

c

MDA-MB-231 cells control; no NPs

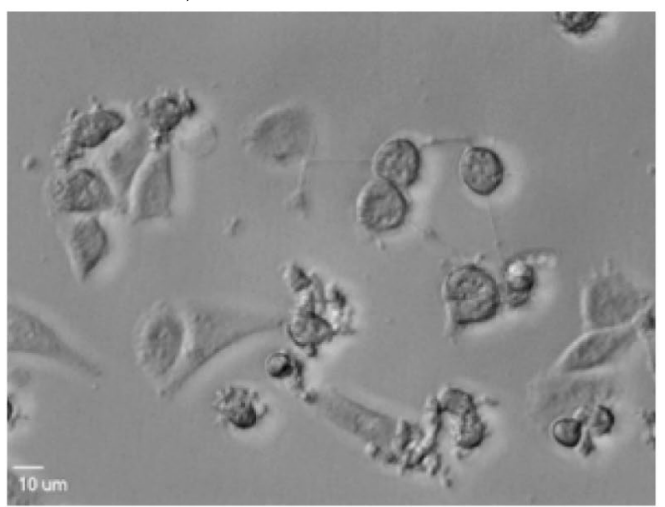

BT-474: $100 \mu \mathrm{g} / \mathrm{ml}$ PLL- $\mathrm{Au}-\mathrm{Fe}_{3} \mathrm{O}_{4}$

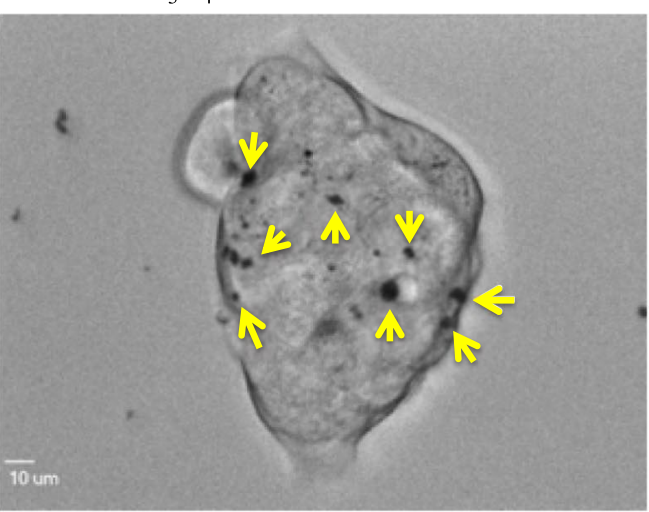

MDA-MB-231: $100 \mu \mathrm{g} / \mathrm{ml}$ PLL- $-\mathrm{Au}-\mathrm{Fe}_{3} \mathrm{O}_{4}$

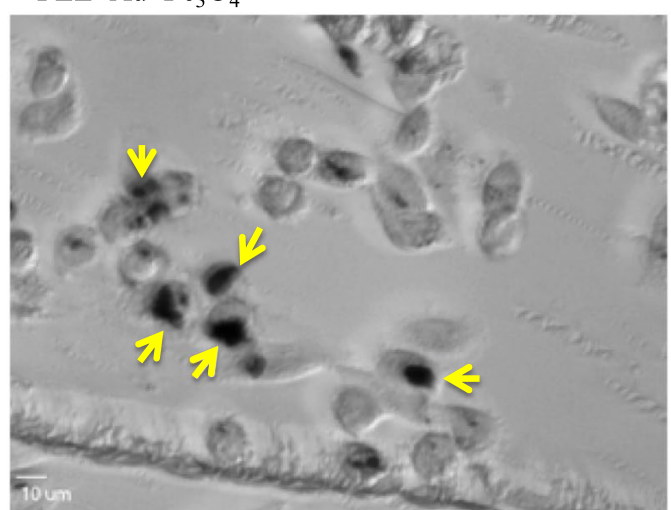

Fig. 4 a Cytotoxicity of PLL-Au-Fe $\mathrm{O}_{4}$ NPs in BT-474 and MDA-MB-231 cells using live-dead assay at increasing NP concentration; Cellular uptake of PLL-Au-Fe $\mathrm{O}_{4}$ NPs in b BT-474 and c MDA-MB-231 cells. Arrows indicate the NPs inside cells. Cells without any NP treatment (control) did not show the black NP dots inside cells. Scale bar $=10 \mu \mathrm{m}$ 
MDA-MB-231 cells is dose-dependent. PLL-Au-Fe $\mathrm{O}_{4}$ NPs did not show much cytotoxicity ( $\leq 20 \%$ cell death) at a concentration $\leq 100 \mu \mathrm{g} / \mathrm{ml}$, and hence the concentration was chosen for subsequent studies. To investigate the intracellular uptake of the NPs, phase contrast images were used. It can be seen from Fig. $4 \mathrm{~b}$ and $\mathrm{c}$ that the $\mathrm{PLL}-\mathrm{Au}-\mathrm{Fe}_{3} \mathrm{O}_{4} \mathrm{NPs}$ (black spots as indicated by arrows) entered in the cytoplasm of BT-474 and MDA-MB-231 cells. No black clusters were found in control cells without any NPs indicating the internalization of NPs by the cells. No morphological changes in cellular physiology have been observed when compared to control cells demonstrating negligible cytotoxicity by $\mathrm{PLL}-\mathrm{Au}-\mathrm{Fe}_{3} \mathrm{O}_{4} \mathrm{NPs}$. The uptake of PLL-Au- $\mathrm{Fe}_{3} \mathrm{O}_{4}$ NPs was further evaluated by TEM imaging (Additional file 1: Figure S4). Clearly, cells treated with NPs show a remarkable distribution inside endoplasmic vesicles of the cells.

\section{Photothermal effects by PLL-Au- $\mathrm{Fe}_{3} \mathrm{O}_{4}$}

In order to investigate, the potential of PLL- $\mathrm{Au}-\mathrm{Fe}_{3} \mathrm{O}_{4}$ as nanothermal ablators, suspensions of the NPs in PBS were irradiated using $808 \mathrm{~nm}$ light emitted by a laser. The photothermal behavior of PLL- $\mathrm{Au}-\mathrm{Fe}_{3} \mathrm{O}_{4}$ NPs was investigated by a temperature change versus the NP concentration (Fig. 5). Clearly, the NPs were able to induce a temperature enhancement in a concentration-dependent manner. The temperature of the NP suspension reached $50{ }^{\circ} \mathrm{C}$ at the PLL- $\mathrm{Au}-\mathrm{Fe}_{3} \mathrm{O}_{4} \mathrm{NP}$ concentration of $800 \mu \mathrm{g} /$ $\mathrm{ml}$. Laser irradiation of PBS negative control without NPs did not show any temperature increase under the same conditions. The results indicate that the synthesized $\mathrm{PLL}-\mathrm{Au}-\mathrm{Fe}_{3} \mathrm{O}_{4}$ NPs were able to transform NIR laser into heat under laser irradiation. For laser treatment,

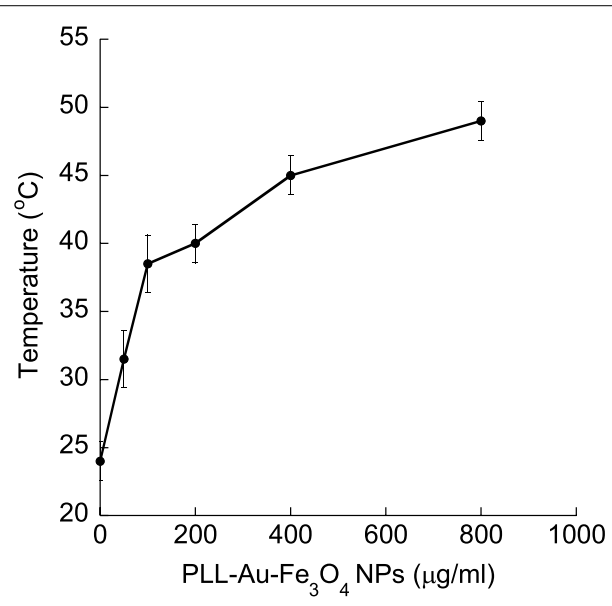

Fig. 5 Temperature change of a PBS solution containing PLL-Au$\mathrm{Fe}_{3} \mathrm{O}_{4} \mathrm{NPs}$ under an $808 \mathrm{~nm}$ laser irradiation as a function of different $\mathrm{NP}$ concentrations
BT-474 and MDA-MB-231 cells were first incubated with PLL-Au- $-\mathrm{Fe}_{3} \mathrm{O}_{4}$ NPs for $2 \mathrm{~h}$ followed by a wash process to remove un-internalized NPs, laser irradiation for $10 \mathrm{~min}$ and then for additional $72 \mathrm{~h}$ incubation period. In the control groups (cells + laser irradiation in absence of NPs), no significant cell death was observed. The cells treated with $100 \mu \mathrm{g} / \mathrm{ml}$ of PLL- $\mathrm{Au}-\mathrm{Fe}_{3} \mathrm{O}_{4} \mathrm{NPs}$ but without laser illumination reached $90 \pm 4.7 \%$ of cell survival rate compared to those treated with PBS control. In contrast, the combination of PLL- $\mathrm{Au}-\mathrm{Fe}_{3} \mathrm{O}_{4} \mathrm{NPs}$ and laser treated cells underwent photothermal destruction as shown by both phase contrast and cell viability (green live cells) and dead cell (red stain) staining (Fig. 6). The groups for PLL-Au- $-\mathrm{Fe}_{3} \mathrm{O}_{4} \mathrm{NPs}+10 \mathrm{~min}$ exposure to laser illumination at $1 \mathrm{~W} / \mathrm{cm}^{2}$ showed the inhibition in cell growth by $49 \pm 12 \%$ in BT-474 cells (Fig. 7; filled circle) and $60 \pm 10 \%$ in MDA-MB-231 cells (Fig. 7; open circle) suggesting significant therapeutic effects following the photothermal treatment. Cells without any treatment, with laser treatment alone and with NP groups showed $\leq 5 \%$ inhibition in cell growth. The cytocompatibility of PLL-Au- $\mathrm{Fe}_{3} \mathrm{O}_{4}$ NPs was further assessed by MTT cell viability assay (Additional file 1: Figure S5). The quantitative analysis further reveals that the percentage of cell viability decreased to $63.5 \pm 5.5 \%$ and $31.6 \pm 3.2 \%$ in BT-474 and MDA-MB-231 cells, respectively at concentrations $\geq 10 \mu \mathrm{g} / \mathrm{ml}$ of NPs following laser irradiation.

\section{Discussion}

A dumbbell-shaped $\mathrm{Au}-\mathrm{Fe}_{3} \mathrm{O}_{4}$ superparamagnetic NPs is synthesized that is similar in morphology to multifaceted Janus particles $[39,40]$. The structure ( $\mathrm{Au}$-decorated $\mathrm{Fe}_{3} \mathrm{O}_{4}$ ) is chosen to provide added advantages of both $\mathrm{Au}$ and $\mathrm{Fe}_{3} \mathrm{O}_{4}$ functionalities for the full utilization of their potential. Several Au dots on the $\mathrm{Fe}_{3} \mathrm{O}_{4}$ host ensures that there is a maximum number of spots for molecular recognition since Au-terminal acts as anchors for targeting agents. Perhaps the most challenging aspect of applying $\mathrm{Au}-\mathrm{Fe}_{3} \mathrm{O}_{4}$ NPs involves the colloidal stability and shelflife, surface functionalization, cellular internalization, and biocompatibility. Designing a properly grafted surface is therefore of paramount importance. Dextran [41], PEG [42], and silica coating [43] have been used extensively, however, each method has its benefits and drawbacks and requires trade-offs and optimizations. For example, although silica coatings can provide colloidal stability, it may also retard $R_{2}$ relaxation in MRI imaging, as well dampen the superparamagnetic moment which reduces hyperthermia efficiency. Reduction in the superparamagnetic moment also leads to the necessity for increased dosage of the magnetic NPs. In that regards, the Januslike particle with larger $\mathrm{Fe}_{3} \mathrm{O}_{4}$ anchored with several $\mathrm{Au}$ dots serves the multifaceted purpose of retaining high 


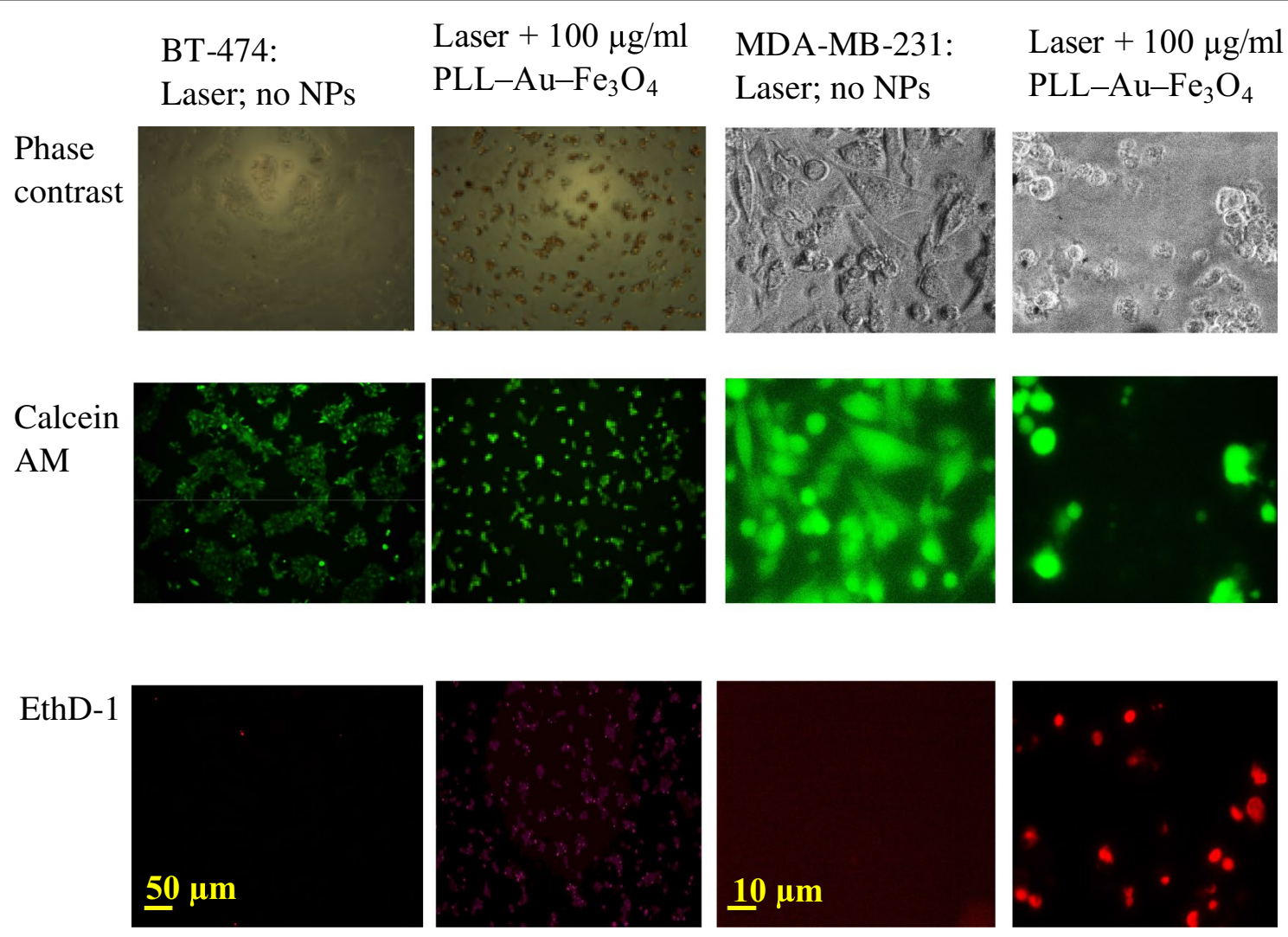

Fig. 6 Phase contrast (row 1) and fluorescence (rows 2 and 3) images of BT-474 and MDA-MB-231 cells treated with $2 \mathrm{~h}$ incubation of PLL-Au$\mathrm{Fe}_{3} \mathrm{O}_{4}$ followed by 10 min laser irradiation and $72 \mathrm{~h}$ of incubation in the medium. Uninternalized NPs were washed with PBS before the imaging. Green fluorescence represents live cells as stained with calcein AM, while the red fluorescence represents dead cells as stained with EthD-1. Scale bars are shown on images

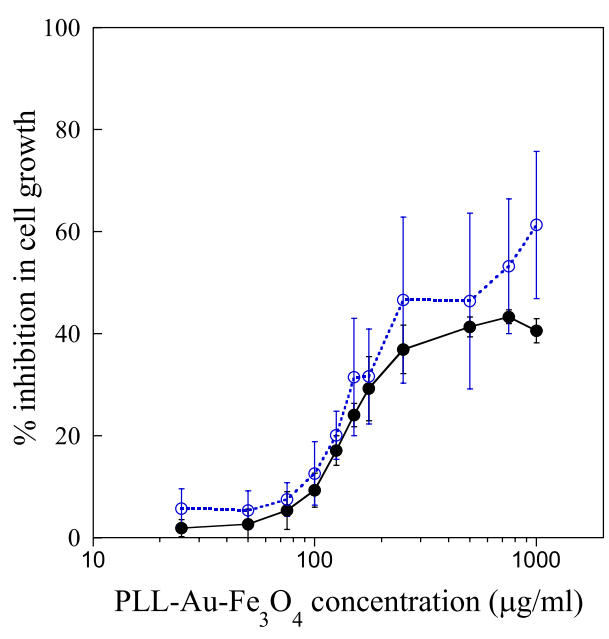

Fig. 7 Quantitative assay of BT-474 (solid line; filled circle) and MDA-MB-231 (dotted line; open circle) cell growth inhibition following photothermal therapy in presence of PBS + laser and $100 \mathrm{\mu g} / \mathrm{ml}$ of PLL-Au-Fe $\mathrm{O}_{4} \mathrm{NPs}$. The data represent the average of three independent experiments superparamagnetic moment over larger size [35] as well as optimizing SPR and photothermal effect of Au. Here, we report a simple and versatile method to adsorb PLL on bare $\mathrm{Au}-\mathrm{Fe}_{3} \mathrm{O}_{4}$ dispersed in aqueous solutions. The polycationic PLL backbone ensures tight coulomb attachment onto anionic surfaces of Au endowing the NP surface with a robust coverage.

This approach can be generalized to many anionic surfaces onto which cationic polymers can adhere tightly, such as glass or silica. The results are comparable with previous studies on $\mathrm{Au}$ nanoshells where polymers (i.e., polyethylene imine; PEI) have been used as an intermediate separating layer during the fabrication of $\mathrm{Au}-\mathrm{Fe}_{3} \mathrm{O}_{4}$ where the polymer layer prevents the migration of $\mathrm{Au}$ shell into the magnetic core by connecting between the core and shell structure $[44,45]$. In contrast, we show an outer layer of PLL on the surface of $\mathrm{Au}-\mathrm{Fe}_{3} \mathrm{O}_{4}$ that attribute to the columbic interactions between the Au surface and aliphatic monoamines that is clearly responsible for the observed stability of $\mathrm{Au}-\mathrm{Fe}_{3} \mathrm{O}_{4}$ against aggregation in PBS. The TEM images showed the presence of a layer 
of PLL of approximately $9 \mathrm{~nm}$ thickness. The PLL coating improved the interaction of negatively charged $\mathrm{Au}-\mathrm{Fe}_{3} \mathrm{O}_{4}$ at the cellular level by the resulting surface charge as confirmed by the zeta potential data.

The next step of PLL-Au- $\mathrm{Fe}_{3} \mathrm{O}_{4}$ involves cell culture experiments that suggest the overall intracellular uptake of the NPs at a non-toxic dose in breast cancer cells. The live/dead assay indicates that PLL- $\mathrm{Au}-\mathrm{Fe}_{3} \mathrm{O}_{4} \mathrm{NPs}$ are not cytotoxic in breast cancer cells at concentrations $\leq 100 \mu \mathrm{g} / \mathrm{ml}$ (Fig. 5). When compared to other cell viability data of polymer-coated NPs, our results are comparable to the literature data showing $20 \%$ reduction in cell viability using similar NP concentrations [45, 46]. Furthermore, the results from the phase contrast imaging microscopy demonstrated the effective internalization of the NPs presumably due to the combination of electrostatic interaction with the negatively charged glycocalyx on the cell membrane $[47,48]$ and the receptormediated endocytosis via EGCG [49-53]. The results are in agreement with the previous finding where $\mathrm{Au}$ NPs functionalized with methoxy-PEG-thiol were internalized by MDA-MB-231 cells via endocytosis [54, 55]. Importantly, the observed uptake of $\mathrm{PLL}-\mathrm{Au}-\mathrm{Fe}_{3} \mathrm{O}_{4}$ NPs by breast cancer cells associated with low toxicity suggest a potential theranostic use of these Au NPs. It is worth noting that PLL- $\mathrm{Au}-\mathrm{Fe}_{3} \mathrm{O}_{4}$ had higher levels of uptake in MDA-MB-231 cells than BT-474 cells. The differences in cell surface protein expressions and proteoglycans may attribute to the differential uptake of NPs inside the cells [56-58]. Importantly, the higher observed uptake of PLL-Au- $\mathrm{Fe}_{3} \mathrm{O}_{4}$ in MDA-MB-231 than BT-474 cells was associated with pronounced toxicity (Fig. 5 and 6) suggesting a potential theranostic use of these gold nanoparticles.

Multiple studies have demonstrated the heating effect of Au shell NPs. Thermal ablation using PEG-coated Au nanoshells with silica cores have been reported to induce photothermal morbidity in SK-BR-3 breast cancer cells [59]. The treated cells revealed lost in cell membrane integrity and cell death that was not observed in the controls with laser irradiation or gold nanoshells alone [59]. Photothermal destruction was effective in reducing colon tumors in mice with a mean survival life of 90 days after the treatment [60]. We found that at $100 \mu \mathrm{g} / \mathrm{ml}$ of PLL$\mathrm{Au}-\mathrm{Fe}_{3} \mathrm{O}_{4}$ and $10 \mathrm{~min}$ laser exposure, a $\Delta \mathrm{T}$ of $15 \pm 7.6{ }^{\circ} \mathrm{C}$ was achieved. The current study reveals the effectiveness of using $\mathrm{PLL}-\mathrm{Au}-\mathrm{Fe}_{3} \mathrm{O}_{4}$ as a potent MRI-visible photosensitizer during the laser irradiation of cancer cells $[45,61,62]$. The noticeable combination of properties of PLL- $\mathrm{Au}-\mathrm{Fe}_{3} \mathrm{O}_{4}$ with the local application of NIR laser irradiation offers a promising approach for the photothermal ablation therapy of breast cancer cells following internalization inside cells.

\section{Conclusions}

A multifunctional NP was constructed using the PLL polymer coating on $\mathrm{Au}-\mathrm{Fe}_{3} \mathrm{O}_{4}$ with a mean diameter of $\sim 60 \mathrm{~nm}$ that are less prone to aggregation and thus suitable for a wide range of biological applications. PLL-Au- $\mathrm{Fe}_{3} \mathrm{O}_{4}$ NPs showed good colloidal stability, NIR light absorption property, magnetic relaxivity and cytocompatibility. Upon exposure to a NIR light, the $\mathrm{SPR}$ of $\mathrm{Au}$ increased their temperature inside the cells. The PLL-Au- $\mathrm{Fe}_{3} \mathrm{O}_{4}$ NPs were also demonstrated the importance of having a surface of the polymer layer that enhanced MRI contrast. As an integrated all-inone NP platform, the polymeric theranostic agent was shown for intracellular uptake and hyperthermal treatments of breast cancer cells for further translational therapeutic applications.

\section{Additional files}

Additional file 1: Figure S1. (a) PLL trypan blue standard curve; and (b) $\mathrm{Au}-\mathrm{Fe} 3 \mathrm{O} 4$ concentration measurement standard line. Figure S2. Hydrodynamic diameters of (a) Au-Fe3O4 NPs and (b) PLL coated AuFe3O4 NPs in water as measured by dynamic light scattering (DLS). Three color codes indicate three independent DLS measurements. Figure S3. Magnetic relaxation (MR) characterization of (A and C) $\mathrm{Au}-\mathrm{Fe} 3 \mathrm{O} 4$ and (Band D) PLL-Au-Fe3O4 NPs. A) Spin-spin MR (T2 ms) of bare Au-Fe3O4 NPs was found to be 190 ms, whereas, it was B) 280 ms for PLL-Au-Fe3O4 NPs at a given concentration of $10 \mu \mathrm{g} / \mathrm{mL}$. This change in T2 MR value is the indicative of effective PLL coatings. Concentration dependent (1-100 $\mu \mathrm{g} / \mathrm{mL}$ ) T2 values were obtained in PBS ( $\mathrm{pH} 7.2$ ) and in $10 \%$ FBS for $\mathbf{C}$ ) $\mathrm{Au}-\mathrm{Fe} 3 \mathrm{O} 4$ and D) PLL-Au-Fe3O4 NPs. These results indicated that with increase in concentration, the MR properties of these NPs increase and were found to be stable in physiological $\mathrm{pH}$ and in sera. Figure S4. The PLL-Au-Fe3O4 NPs uptake by (a) BT-474 and (b) MDA-MB-231 cells after $24 \mathrm{~h}$ incubation. Red circles indicate the endosomal vesicles that clearly retain the NPs as appeared in dark black spots. Figure S5. MTT cell viability assay of BT-474 (filled circle, solid line) and MDA-MB-231 (open circle, dotted line) cell viability after treatment with PLL-Au-Fe3O4 NPs under a $650 \mathrm{~nm}$ laser irradiation for $10 \mathrm{~min}$. Table S1. The percentage encapsulation efficiency of PLL on Au-Fe3O4 NPs.

Additional file 2: Movie S1. This video shows Au-Fe3O4 (left) and PLLAu-Fe3O4 NPs (right) where PLL coating prevents NP settle down in water and therefore black PLL-Au-Fe3O4 NPs' colloidal suspension is observed.

\section{Authors' contributions}

MRA performed the polymer coating on nanoparticles, characterization of nanoparticles, cell culture, cytotoxicity assays and revised the manuscript. $\mathrm{HM}$ and TL initiated the study, performed laser experiments and drafted the manuscript. SU and HC synthesized and characterized the nanoparticles. SU also wrote the XRD, FT-IR and TGA sections of the manuscript. DM and SS performed the MR experiments and wrote the MRI section of the manuscript. MN supervised the nanoparticle synthesis and revised the manuscript. SB supervised data interpretations, drafted the manuscript and revised the manuscript. All authors read and approved the final manuscript.

\section{Author details}

${ }^{1}$ Department of Chemical and Biochemical Engineering, Missouri University of Science and Technology, 110 Bertelsmeyer Hall, 1101 N. State Street, Rolla, MO 65409-1230, USA. ${ }^{2}$ Department of Chemistry, Missouri University 
of Science and Technology, Rolla, MO 65409, USA. ${ }^{3}$ Department of Chemistry, Pittsburg State University, Pittsburg, KS 66762, USA.

\section{Acknowledgements}

For this work, we would like to acknowledge the Environmental Research Center (ERC) and Materials Research Center (MRC) at Missouri S\&T for TEM and Zetasizer use. The authors would like to thank Dr. Hai-Lung Tsai of the Department of Mechanical Engineering at Missouri S\&T to allow us using their laser facility.

\section{Competing interests}

The authors declare that they have no competing interests.

\section{Funding}

This research was funded by S.B.'s start-up; and American Chemical Society Petroleum Research Fund (ACS PRF 56629-UNI7) and Kansas IDeA Network of Biomedical Research Excellence at Pittsburg State University (K-INBRE P20GM103418) to S.S.

\section{Publisher's Note}

Springer Nature remains neutral with regard to jurisdictional claims in published maps and institutional affiliations.

Received: 30 November 2017 Accepted: 28 September 2018 Published online: 13 October 2018

\section{References}

1. Key J, Park K. Multicomponent, tumor-homing chitosan nanoparticles for cancer imaging and therapy. Int J Mol Sci. 2017;18:594

2. Ma Y, Liang XL, Tong S, Bao G, Ren QS, Dai ZF. Gold nanoshell nanomicelles for potential magnetic resonance imaging, light-triggered drug release, and photothermal therapy. Adv Func Mater. 2013;23:815-22.

3. Bammer R, Skare S, Newbould R, Liu C, Thijs V, Ropele S, Clayton DB, Krueger G, Moseley ME, Glover GH. Foundations of advanced magnetic resonance imaging. NeuroRx. 2005;2:167-96.

4. Belyanina I, Kolovskaya O, Zamay S, Gargaun A, Zamay T, Kichkailo A Targeted magnetic nanotheranostics of cancer. Molecules. 2017;22:975.

5. Chen CW, Syu WJ, Huang TC, Lee YC, Hsiao JK, Huang KY, Yu HP, Liao MY, Lai PS. Encapsulation of Au/Fe3O4 nanoparticles into a polymer nanoarchitecture with combined near infrared-triggered chemo-photothermal therapy based on intracellular secondary protein understanding. J Mater Chem B. 2017;5:5774-82.

6. Hu J, Dehsorkhi A, Al-Jamal WT, Zhang Y, Chen SY, Yang CY, Tan D, Zhao Q, Yang C, Wang YL. Studies on the photothermal effect of PEGylated Fe3O4 nanoparticles. Nanosci Nanotechnol Lett. 2017;9:556-61.

7. Tang JL, Zhou HG, Liu JM, Liu J, Li WQ, Wang YQ, Hu F, Huo Q, Li JY, Liu Y, Chen CY. Dual-mode imaging-guided synergistic chemo- and magnetohyperthermia therapy in a versatile nanoplatform to eliminate cancer stem cells. ACS Appl Mater Interfaces. 2017;9:23497-507.

8. Wang YXJ, Idee JM. A comprehensive literatures update of clinical researches of superparamagnetic resonance iron oxide nanoparticles for magnetic resonance imaging. Quant Imaging Med Surg. 2017;7:88-122.

9. Yang HY, Jang MS, Li Y, Lee JH, Lee DS. Multifunctional and redoxresponsive self-assembled magnetic nanovectors for protein delivery and dual-modal imaging. ACS Appl Mater Interfaces. 2017;9:19184-92.

10. Yang RM, Fu CP, Fang JZ, Xu XD, Wei XH, Tang WJ, Jiang XQ, Zhang LM. Hyaluronan-modified superparamagnetic iron oxide nanoparticles for bimodal breast cancer imaging and photothermal therapy. Int J Nanomed. 2017;12:197-206.

11. Hemery G, Garanger E, Lecommandoux S, Wong AD, Gillies ER, Pedrono B, Bayle T, Jacob D, Sandre O. Thermosensitive polymer-grafted iron oxide nanoparticles studied by in situ dynamic light backscattering under magnetic hyperthermia. J Phys D Appl Phys. 2015;48:494001.

12. Kale SS, Burga RA, Sweeney EE, Zun ZH, Sze RW, Tuesca A, Subramony $J A$, Fernandes R. Composite iron oxide-Prussian blue nanoparticles for magnetically guided T-1-weighted magnetic resonance imaging and photothermal therapy of tumors. Int J Nanomed. 2017;12:6413-24.
13. Narayanan S, Sathy BN, Mony U, Koyakutty M, Nair SV, Menon D. Biocompatible magnetite/gold nanohybrid contrast agents via green chemistry for MRI and CT bioimaging. ACS Appl Mater Interfaces. 2012;4:251-60.

14. Salah EDTA, Bakr MM, Kamel HM, Abdel KM. Magnetite nanoparticles as a single dose treatment for iron deficiency anemia. Google Patents, WO2010034319A1, 01 Apr 2010. 2010.

15. Thiesen B, Jordan A. Clinical applications of magnetic nanoparticles for hyperthermia. Int J Hyperth. 2008;24:467-74.

16. Bashir MR, Bhatti L, Marin D, Nelson RC. Emerging applications for ferumoxytol as a contrast agent in MRI. J Magn Reson Imaging. 2015:41:884-98.

17. Kharlamov AN, Gabinsky JL. Plasmonic photothermic and stem cell therapy of atherosclerotic plaque as a novel nanotool for angioplasty and artery remodeling. Rejuvenation Res. 2012;15:222-30.

18. Pisanic TR, Blackwell JD, Shubayev VI, Fiñones RR, Jin S. Nanotoxicity of iron oxide nanoparticle internalization in growing neurons. Biomaterials. 2007;28:2572-81

19. Hanini A, Schmitt A, Kacem K, Chau F, Ammar S, Gavard J. Evaluation of iron oxide nanoparticle biocompatibility. Int J Nanomed. 2011;6:787-94.

20. Zhang X-D, Wu D, Shen X, Liu P-X, Fan F-Y, Fan S-J. In vivo renal clearance, biodistribution, toxicity of gold nanoclusters. Biomaterials. 2012;33:4628-38

21. Siddiqi NJ, Abdelhalim MAK, El-Ansary AK, Alhomida AS, Ong WY. Identification of potential biomarkers of gold nanoparticle toxicity in rat brains. J Neuroinflammation. 2012;9:123.

22. Joris F, Valdeperez D, Pelaz B, Soenen SJ, Manshian BB, Parak WJ, De Smedt SC, Raemdonck K. The impact of species and cell type on the nanosafety profile of iron oxide nanoparticles in neural cells. J Nanobiotechnol. 2016;14:69.

23. Lewinski N, Colvin V, Drezek R. Cytotoxicity of nanoparticles. Small. 2008:4:26-49.

24. Escamilla-Rivera V, Uribe-Ramirez M, Gonzalez-Pozos S, Lozano O, Lucas S, De Vizcaya-Ruiz A. Protein corona acts as a protective shield against Fe3O4-PEG inflammation and ROS-induced toxicity in human macrophages. Toxicol Lett. 2016;240:172-84.

25. Soenen SJ, Rivera-Gil P, Montenegro J-M, Parak WJ, De Smedt SC, Braeckmans K. Cellular toxicity of inorganic nanoparticles: common aspects and guidelines for improved nanotoxicity evaluation. Nano Today. 2011;6:446-65

26. Smith BM, Pike DJ, Kelly MO, Nason JA. Quantification of heteroaggregation between citrate-stabilized gold nanoparticles and hematite colloids. Environ Sci Technol. 2015;49:12789-97.

27. Shiraishi K, Kawano K, Maitani Y, Yokoyama M. Polyion complex micelle MRI contrast agents from poly(ethylene glycol)-b-poly(L-lysine) block copolymers having Gd-DOTA; preparations and their control of T1-relaxivities and blood circulation characteristics. J Control Release. 2010;148:160-7.

28. Al-Jamal KT, Al-Jamal WT, Akerman S, Podesta JE, Yilmazer A, Turton JA, Bianco A, Vargesson N, Kanthou C, Florence AT, Tozer GM, Kostarelos K. Systemic antiangiogenic activity of cationic poly-L-lysine dendrimer delays tumor growth. Proc Natl Acad Sci USA. 2010;107:3966-71.

29. Tunyaboon L, Hannah HK, Kelly D, Caitlin B, Dipak B, Daniel F, Yue-Wern H, Sutapa B. Bioresponsive polymer coated drug nanorods for breast cancer treatment. Nanotechnology. 2017;28:045601.

30. Alconcel SNS, Baas AS, Maynard HD. FDA-approved poly(ethylene glycol)protein conjugate drugs. Polym Chem. 2011;2:1442-8.

31. Vexler VS, Clément O, Schmitt-Willich $H$, Brasch RC. Effect of varying the molecular weight of the MR contrast agent Gd-DTPA-polylysine on blood pharmacokinetics and enhancement patterns. J Magn Reson Imaging. 1994:4:381-8

32. Bogdanov A, Wright SC, Marecos EM, Bogdanova A, Martin C, Petherick P, Weissleder R. A long-circulating co-polymer in "passive targeting" to solid tumors. J Drug Target. 1997;4:321.

33. Gref R, Lück M, Quellec P, Marchand M, Dellacherie E, Harnisch S, Blunk T, Müller RH. 'Stealth' corona-core nanoparticles surface modified by polyethylene glycol (PEG): influences of the corona (PEG chain length and surface density) and of the core composition on phagocytic uptake and plasma protein adsorption. Colloids Surf B. 2000;18:301-13.

34. Amstad E, Zurcher S, Mashaghi A, Wong JY, Textor M, Reimhult E. Surface functionalization of single superparamagnetic iron oxide nanoparticles for targeted magnetic resonance imaging. Small. 2009;5:1334-42. 
35. Pariti A, Desai P, Maddirala SKY, Ercal N, Katti KV, Liang X, Nath M. Superparamagnetic Au-Fe3O4 nanoparticles: one-pot synthesis, biofunctionalization and toxicity evaluation. Mater Res Express. 2014;1:035023.

36. Grotzky A, Manaka Y, Fornera S, Willeke M, Walde P. Quantification of [small alpha]-polylysine: a comparison of four UV/Vis spectrophotometric methods. Anal Methods. 2010;2:1448-55.

37. Luo R, Mutukumaraswamy S, Venkatraman SS, Neu B. Engineering of erythrocyte-based drug carriers: control of protein release and bioactivity. J Mater Sci Mater Med. 2012:23:63-71.

38. Lou L, Yu K, Zhang Z, Huang R, Wang Y, Zhu Z. Facile methods for synthesis of core-shell structured and heterostructured Fe304@Au nanocomposites. Appl Surf Sci. 2012;258:8521-6.

39. Lattuada M, Hatton TA. Synthesis, properties and applications of Janus nanoparticles. Nano Today. 2011;6:286-308.

40. Perro A, Reculusa S, Ravaine S, Bourgeat-Lami E, Duguet E. Design and synthesis of Janus micro- and nanoparticles. J Mater Chem. 2005; 15:3745-60.

41. Li W, Tutton S, Vu AT, Pierchala L, Li BSY, Lewis JM, Prasad PV, Edelman RR. First-pass contrast-enhanced magnetic resonance angiography in humans using ferumoxytol, a novel ultrasmall superparamagnetic iron oxide (USPIO)-based blood pool agent. J Magn Reson Imaging. 2005:21:46-52.

42. Shen JW, Li KY, Cheng L, Liu Z, Lee ST, Liu J. Specific detection and simultaneously localized photothermal treatment of cancer cells using layer-by-layer assembled multifunctional nanoparticles. ACS Appl Mater Interfaces. 2014;6:6443-52.

43. Pinho SLC, Pereira GA, Voisin P, Kassem J, Bouchaud V, Etienne L, Peters JA, Carlos L, Mornet S, Geraldes CFGC, Rocha J, Delville M-H. Fine tuning of the relaxometry of $y$-Fe2O3@SiO2 nanoparticles by tweaking the silica coating thickness. ACS Nano. 2010;4:5339-49.

44. Goon IY, Lai LMH, Lim M, Munroe P, Gooding JJ, Amal R. Fabrication and dispersion of gold-shell-protected magnetite nanoparticles: systematic control using polyethyleneimine. Chem Mater. 2009;21:673-81.

45. Hoskins C, Min Y, Gueorguieva M, McDougall C, Volovick A, Prentice P, Wang Z, Melzer A, Cuschieri A, Wang L. Hybrid gold-iron oxide nanoparticles as a multifunctional platform for biomedical application. J Nanobiotechnol. 2012;10:27

46. Hoskins C, Cuschieri A, Wang L. The cytotoxicity of polycationic iron oxide nanoparticles: common endpoint assays and alternative approaches for improved understanding of cellular response mechanism. J Nanobiotechnol. 2012;10:15.

47. Schweiger C, Hartmann R, Zhang F, Parak WJ, Kissel TH, Rivera_Gil P. Quantification of the internalization patterns of superparamagnetic iron oxide nanoparticles with opposite charge. J Nanobiotechnol. 2012;10:28.

48. Ojea-Jiménez I, García-Fernández L, Lorenzo J, Puntes VF. Facile preparation of cationic gold nanoparticle-bioconjugates for cell penetration and nuclear targeting. ACS Nano. 2012;6:7692-702.
49. Ahmad N, Feyes DK, Agarwal R, Mukhtar H, Nieminen A-L. Green tea constituent epigallocatechin-3-gallate and induction of apoptosis and cell cycle arrest in human carcinoma cells. JNCI J Natl Cancer Inst. 1997;89:1881-6.

50. Liang Y-C, Lin-shiau S-Y, Chen C-F, Lin J-K. Suppression of extracellular signals and cell proliferation through EGF receptor binding by (-)-epigallocatechin gallate in human A431 epidermoid carcinoma cells. J Cell Biochem. 1997;67:55-65.

51. Pianetti S, Guo S, Kavanagh KT, Sonenshein GE. Green tea polyphenol epigallocatechin-3 gallate inhibits Her-2/Neu signaling, proliferation, and transformed phenotype of breast cancer cells. Can Res. 2002;62:652-5.

52. Tachibana $H$, Koga K, Fujimura $Y$, Yamada K. A receptor for green tea polyphenol EGCG. Nat Struct Mol Biol. 2004;11:380.

53. Shukla R, Chanda N, Zambre A, Upendran A, Katti K, Kulkarni RR, Nune SK, Casteel SW, Smith CJ, Vimal J, Boote E, Robertson JD, Kan P, Engelbrecht H, Watkinson LD, Carmack TL, Lever JR, Cutler CS, Caldwell C, Kannan R, Katti KV. Laminin receptor specific therapeutic gold nanoparticles (198AuNPEGCg) show efficacy in treating prostate cancer. Proc Natl Acad Sci. 2012;109:12426-31.

54. Shukla R, Bansal V, Chaudhary M, Basu A, Bhonde RR, Sastry M. Biocompatibility of gold nanoparticles and their endocytotic fate inside the cellular compartment: a microscopic overview. Langmuir. 2005;21:10644-54.

55. Shenoy D, Fu W, Li J, Crasto C, Jones G, DiMarzio C, Sridhar S, Amiji M. Surface functionalization of gold nanoparticles using hetero-bifunctional poly(ethylene glycol) spacer for intracellular tracking and delivery. Int J Nanomed. 2006;1:51-7.

56. Holliday DL, Speirs V. Choosing the right cell line for breast cancer research. Breast Cancer Res. 2011;13:215.

57. Sheridan C, Kishimoto H, Fuchs RK, Mehrotra S, Bhat-Nakshatri P, Turner $\mathrm{CH}$, Goulet R, Badve S, Nakshatri H. CD44+/CD24-breast cancer cells exhibit enhanced invasive properties: an early step necessary for metastasis. Breast Cancer Res. 2006;8:R59.

58. Lacroix M, Leclercq G. Relevance of breast cancer cell lines as models for breast tumours: an update. Breast Cancer Res Treat. 2004;83:249-89.

59. Hirsch LR, Stafford RJ, Bankson JA, Sershen SR, Rivera B, Price RE, Hazle JD, Halas NJ, West JL. Nanoshell-mediated near-infrared thermal therapy of tumors under magnetic resonance guidance. Proc Natl Acad Sci. 2003;100:13549-54.

60. Hirsch LR, Gobin AM, Lowery AR, Tam F, Drezek RA, Halas NJ, West JL. Metal nanoshells. Ann Biomed Eng. 2006:34:15-22.

61. Sciortino F, Casterou G, Eliat PA, Troadec MB, Gaillard C, Chevance S, Kahn ML, Gauffre F. Simple engineering of polymer-nanoparticle hybrid nanocapsules. Chemnanomat. 2016;2:796-9.

62. Yang D, Yang GX, Gai SL, He F, Lv RC, Dai YL, Yang PP. Imaging-guided and light-triggered chemo-/photodynamic/photothermal therapy based on $\mathrm{Gd}(\mathrm{III})$ chelated mesoporous silica hybrid spheres. Acs Biomater Sci Eng. 2016;2:2058-71.

\footnotetext{
Ready to submit your research? Choose BMC and benefit from:

- fast, convenient online submission

- thorough peer review by experienced researchers in your field

- rapid publication on acceptance

- support for research data, including large and complex data types

- gold Open Access which fosters wider collaboration and increased citations

- maximum visibility for your research: over $100 \mathrm{M}$ website views per year
}

At BMC, research is always in progress.

Learn more biomedcentral.com/submissions 